\title{
Progress towards antimicrobial resistance containment and control in Indonesia
}

\author{
A pilot programme to evaluate Indonesia's antimicrobial resistance containment plan shows that \\ progress is on the right track, but substantial strengthening is needed, say Harry Parathon and \\ colleagues
}

n May 2015 member states at the World Health Assembly endorsed the World Health Organization's global action plan on antimicrobial resistance (GAPAMR). ${ }^{1}$ Through adoption of the GAPAMR, member states committed to having a national action plan on antimicrobial resistance in place by May $2017 .{ }^{12}$ The South East Asia region has moved from having one $(10 \%)$ country with a national action plan in December 2015 to 10 countries (90\%) by May 2017. WHO supported the Indonesian Ministry of Health to develop a national action plan, first by conducting a review of current activities. ${ }^{3}$ The review focused on a situation analysis of challenges to tackling AMR. The South East Asia Regional Office (SEARO) of WHO has proposed a stepwise, incremental approach to implementing GAP-AMR, consisting of five phases. Phase 5 is defined as a fully operational AMR containment programme with evidence of a sustained funding mechanism and incorporating a functional monitoring and evaluation system. Here we evaluate Indonesia's progress towards this goal.

\section{KEY MESSAGES}

- A national action plan to combat antimicrobial resistance (AMR) in line with the Global Action Plan was finalised and shared with WHO before the WHO General Assembly in May 2017

- Indonesia's programme to contain AMR is in the early phase of implementation based on the situation analysis tool produced by the South East Asia Regional Office of WHO

- A substantial achievement of the programme in the past year was the provision of considerable national funds to support national activities to combat AMR

- Indonesia's health authorities recognised many major challenges including setting up a strong governance that incorporates a multisectoral collaboration and coordination, national surveillance of AMR and enforcement of policies for rational use of antibiotics and AMR stewardship

\section{Antimicrobial resistance in Indonesia}

With an estimated population of 258 million people, Indonesia is the fourth most populous country in the world and is categorised as a lower middle income country. ${ }^{4}$ Despite no formal estimation of its burden, AMR is thought to be high and on the rise. Data on AMR in Indonesia have been patchy, sporadic, and selective, commonly generated by a few laboratories from large universities, which are not connected in a national network. ${ }^{5}$

Epidemiological data on Streptococcus pneumoniae carriage and invasive disease are currently limited in Indonesia. ${ }^{6}$ In the mid 1990s studies reported $21 \%$ and $36 \%$ of penicillin non-susceptible and erythromycin resistant $S$ pneumoniae, respectively, in Jakarta. ${ }^{7}$ In Lombok Island, the prevalence of $S$ pneumoniae carriage was $48 \%$ in healthy children, of which all isolates were susceptible to penicillin and cefotaxime and $12 \%$ were non-susceptible to sulfamethoxazole or chloramphenicol. ${ }^{8}$ In 2000-01, the prevalence of tetracycline resistant $S$ pneumoniae tested at the University of Jakarta's microbiology laboratory was $46 \%$, compared with $1-5 \%$ in studies from northern Europe. ${ }^{79}$ In Semarang, Indonesia, prevalence of $S$ pneumoniae in 2010 was $43 \%$ in children aged 6-60 months and $11 \%$ in adults aged 45-75 years, of which isolates $24 \%$ were penicillin non-susceptible and $45 \%$ were resistant to cotrimoxazole. ${ }^{10}$

In 2001, E coli from rectal samples showed remarkably high resistance to ampicillin (73\%), trimethoprimsulfamethoxazole (56\%) and ciprofloxacin (22\%), especially at the time of hospital discharge. ${ }^{11}$ Until the late 1990s, extended spectrum $\beta$ lactamase producing bacteria were mainly isolated in hospitals worldwide; later, resistance increased along with the emergence of genes related to CTX-M in hospitals and the community. ${ }^{12} 13$ In 2005 a survey in a hospital in Surabaya, Indonesia, found prevalences of extended spectrum $\beta$ lactamases (including CTX-M) of 20\% and $28 \%$ among clinical $E$ coli and Klebsiella pneumoniae, respectively. ${ }^{14}$

Over the past decade the emergence of extended spectrum $\beta$ lactamase producing bacteria and carbapenem resistant Enterobacteriaceae has become a worldwide threat to public health. From 2001 to 2012, resistance to imipenem rates reached 30\% in some epidemic areas of the Middle East, while the top two Asian countries with the highest resistance rates to imipenem were Indonesia (6\%) and the Philippines (4\%). ${ }^{151617}$ In 2009 the gene for New Delhi metallo- $\beta$-lactamase (bla $\mathrm{NDM}_{\mathrm{ND}-1}$ ) was found in a sample of $K$ pneumoniae in Indonesia. $^{18}$

In 2001-02 the nasal carriage of Staphylococcus aureus was surveyed in two cities on Java island (Semarang and Surabaya); low prevalence of meticillin resistant $S$ aureus (MRSA) $(<1 \%)$ was found among 263 isolates from healthy people in the community. ${ }^{19}$ In 2007-08, 24\% of surgical patients were screened for MRSA carriage at discharge in three teaching hospitals in Indonesia. Of these, $24 \%$ patients carried $S$ Aureus, $4.3 \%$ of whom had MRSA. This was surprising low, as the prevalence of MRSA in some Asian countries, such as Taiwan and mainland China, is among the highest in the world, ranging from $28 \%$ to over $70 \% .{ }^{2021}$ Prevention of spread of MRSA is crucial in Indonesia because of the surprisingly high prevalence of the PantonValentine leukocidin genes (11\%) among MRSA in the country, a virulence factor that is associated with skin infections and severe necrotising pneumonia. ${ }^{22}$

The challenges of AMR that Indonesia faces are similar as those of many other low and middle income countries in the region and beyond. Misuse and overuse of antibiotics in humans and in livestock and aquaculture are the key drivers of resistance in the country. With the economy prospering for the past decade and a growing demand for poultry products and the development of aquaculture exports, agricultural use probably exceeds medical use in Indonesia. ${ }^{23}$ Despite current policies related to antimicrobial use, common and unnecessary prescription of antibiotics by physicians, high rates of self medication, and over-the-counter purchase of antibiotics are common. ${ }^{24}$ Many contextual factors influencing antibiotic use are known, including weak policy enforcement and poor governance, lack of education, and easy access to cheap antibiotics. ${ }^{25}$ 


\section{Situational analysis methods}

The Indonesian ministry of health agreed to pilot the situation analysis tool developed by SEARO, the objectives of which are to report on the baseline, development, implementation, monitoring, and evaluating progress made by the national AMR prevention and containment programme. ${ }^{3}$ The tool has seven focus areas consistent with the strategic objectives of the GAP-AMR: national AMR action plan in line with GAP-AMR; AMR awareness raising; national AMR surveillance; antimicrobial stewardship and surveillance of antimicrobial use and consumption in the community; infection prevention control in healthcare settings; research and innovation to combat AMR; and One Health engagement. Each focus area is composed of a list of indicators that are graded on five levels to show the incremental extent of AMR programme implementation.
The situation analysis process consists of guided discussions between members of the ministry of health's AMR control committee, senior technical leaders of the national health authorities, the veterinary, agriculture and food sector, and a WHO team. The situation analysis focuses on the level of development of the national AMR containment programme in terms of governance structure, policy, and systems. It is a broad system analysis rather than assessing quality of official documents such as guidelines, regulations, and policies. Details of the definitions and methodology of the situation analysis tool are described elsewhere. $^{3}$

\section{Monitoring Indonesia's progress}

The results of situation analysis are summarised in table 1 . The review confirmed that the AMR containment programme is in the early phase of implementation, ranging from programme installation to full operation phases for most of the core activities of the GAP-AMR. Since 2016 the ministry of health has boosted the programme, with substantial funding for the national AMR control committee. The AMR prevention and control programme is on the right track but needs further strengthening.

The Indonesian authorities are committed to supporting AMR containment activities and understand the complexity of AMR and its challenges in Indonesia, particularly multisectoral coordination and policy enforcement issues. This review of the situation was useful in several ways. Firstly, it emphasised among multidisciplinary participants that a comprehensive One Health approach-that is, coordination and collaboration between the human, animal, and the environmental

\begin{tabular}{|c|c|c|c|c|c|c|}
\hline \multirow[b]{2}{*}{ Indicators } & \multicolumn{5}{|l|}{ Phases } & \multirow[b]{2}{*}{$\begin{array}{l}\text { Phase achieved } \\
\text { in Indonesia }\end{array}$} \\
\hline & $\begin{array}{l}\text { 1-Exploration and } \\
\text { adoption }\end{array}$ & $\begin{array}{l}\text { 2-Programme } \\
\text { installation }\end{array}$ & 3-Initial implementation & 4-Full operation & $\begin{array}{l}\text { 5-Sustainable } \\
\text { operation }\end{array}$ & \\
\hline \multicolumn{7}{|c|}{ 1. National AMR action plan } \\
\hline $\begin{array}{l}\text { NAP in line with } \\
\text { GAP-AMRGAP }\end{array}$ & $\begin{array}{l}\text { No action plan or no } \\
\text { national multisectoral } \\
\text { committee or AMR } \\
\text { committee established } \\
\text { but involving one } \\
\text { ministry }\end{array}$ & $\begin{array}{l}\text { AMR working group } \\
\text { established and } \\
\text { national action plan } \\
\text { under way }\end{array}$ & $\begin{array}{l}\text { Action plan aligned with } \\
\text { GAP including operational } \\
\text { plan with defined activities } \\
\text { and respective budget } \\
\text { available }\end{array}$ & $\begin{array}{l}\text { Action plan includes } \\
\text { operational plan being } \\
\text { rolled out and scaled up } \\
\text { with defined activities and } \\
\text { respective budget }\end{array}$ & $\begin{array}{l}\text { Action plan includes } \\
\text { operational plan being } \\
\text { rolled out and scaled up } \\
\text { with defined activities and } \\
\text { respective budget }\end{array}$ & $2+$ \\
\hline \multicolumn{7}{|l|}{ 2. Awareness raising } \\
\hline $\begin{array}{l}\text { Awareness campaigns to } \\
\text { the public }\end{array}$ & $\begin{array}{l}\text { Government not } \\
\text { involved in awareness } \\
\text { raising activities on } \\
\text { antibiotic resistance }\end{array}$ & $\begin{array}{l}\text { Some government } \\
\text { led activities in parts } \\
\text { of the country to raise } \\
\text { awareness about AMR } \\
\text { and actions to tackle it }\end{array}$ & $\begin{array}{l}\text { Nationwide, government } \\
\text { led antibiotic awareness } \\
\text { campaign targeting } \\
\text { the general public or } \\
\text { professionals }\end{array}$ & $\begin{array}{l}\text { Nationwide, government } \\
\text { led antibiotic awareness } \\
\text { campaign targeting public } \\
\text { and professionals }\end{array}$ & $\begin{array}{l}\text { Assessing effects } \\
\text { of government led } \\
\text { awareness campaigns } \\
\text { on behaviour changes in } \\
\text { public and professionals }\end{array}$ & $3+$ \\
\hline $\begin{array}{l}\text { Education and } \\
\text { training strategies for } \\
\text { professionals }\end{array}$ & No policy or strategy & $\begin{array}{l}\text { Relevant policies } \\
\text { developed but ad hoc } \\
\text { training courses in } \\
\text { some disciplines }\end{array}$ & $\begin{array}{l}\text { AMR included in some } \\
\text { preservice training or } \\
\text { special courses or both } \\
\text { OR } \\
\text { Continuous professional } \\
\text { development and regular } \\
\text { audit of learning }\end{array}$ & $\begin{array}{l}\text { AMR included in some } \\
\text { preservice training or } \\
\text { some special courses } \\
\text { or both } \\
\text { AND } \\
\text { Continuous professional } \\
\text { development and regular } \\
\text { audit of learning }\end{array}$ & $\begin{array}{l}\text { AMR included in } \\
\text { preservice training for all } \\
\text { relevant cadres } \\
\text { Regular continuing } \\
\text { professional development }\end{array}$ & $3+$ \\
\hline \multicolumn{7}{|c|}{ 3. National AMR surveillance system } \\
\hline $\begin{array}{l}\text { National human AMR } \\
\text { surveillance }\end{array}$ & $\begin{array}{l}\text { No capacity for AMR } \\
\text { laboratory or limited } \\
\text { reporting or both, or no } \\
\text { surveillance guidelines }\end{array}$ & $\begin{array}{l}\text { Guidelines developed } \\
\text { but not fully } \\
\text { implemented. Limited } \\
\text { quality data and } \\
\text { analysis and not fully } \\
\text { representative of country }\end{array}$ & $\begin{array}{l}\text { Standardised national AMR } \\
\text { surveillance in place and } \\
\text { representative of country } \\
\text { but limited number of } \\
\text { operational sites }\end{array}$ & $\begin{array}{l}\text { Surveillance in place and } \\
\text { functional to monitor AMR } \\
\text { trends accurately and } \\
\text { timely but no contributing } \\
\text { data to GLASS }\end{array}$ & $\begin{array}{l}\text { National AMR surveillance } \\
\text { regularly assessed and } \\
\text { adjusted; and contributing } \\
\text { to GLASS }\end{array}$ & $2-$ \\
\hline $\begin{array}{l}\text { National laboratory } \\
\text { network strengthening }\end{array}$ & $\begin{array}{l}\text { No national network } \\
\text { developed }\end{array}$ & $\begin{array}{l}\text { A national network with } \\
\text { testing according to the } \\
\text { international standards } \\
\text { is planned }\end{array}$ & $\begin{array}{l}\text { A national reference } \\
\text { laboratory is identified, } \\
\text { and quality assured } \\
\text { laboratory networks have } \\
\text { been developed only at few } \\
\text { surveillance sites }\end{array}$ & $\begin{array}{l}\text { A national network of EQA } \\
\text { health laboratories has } \\
\text { been developed in most } \\
\text { or all surveillance sites }\end{array}$ & $\begin{array}{l}\text { A laboratory network } \\
\text { is established, EQA } \\
\text { measures are in place, and } \\
\text { the reference laboratory } \\
\text { has demonstrated capacity } \\
\text { for research }\end{array}$ & 1 \\
\hline $\begin{array}{l}\text { A national AMR } \\
\text { containment policy for } \\
\text { control of human use } \\
\text { of antimicrobials; AMR } \\
\text { stewardship (AMS) }\end{array}$ & $\begin{array}{l}\text { No or weak national } \\
\text { policy and plan, } \\
\text { regulations for } \\
\text { antimicrobial use, and } \\
\text { availability }\end{array}$ & $\begin{array}{l}\text { National AMS } \\
\text { programme (AMSP) } \\
\text { planned and under } \\
\text { development }\end{array}$ & $\begin{array}{l}\text { AMSP is developed, } \\
\text { including tools to } \\
\text { implement and monitor } \\
\text { AMS progress and impact }\end{array}$ & $\begin{array}{l}\text { AMSP implemented by } \\
\text { relevant institutions. } \\
\text { Regulations for } \\
\text { antimicrobial use } \\
\text { and availability are } \\
\text { implemented in limited } \\
\text { capacity }\end{array}$ & $\begin{array}{l}\text { A national AMSP for } \\
\text { control of human use } \\
\text { of antimicrobials has } \\
\text { been implemented and } \\
\text { enforced for more than } \\
2 \text { years }\end{array}$ & 4 \\
\hline
\end{tabular}




\section{Table 1 | Continued}

\section{Indicators}

National Regulatory Authorities (NRA) or Drug Regulatory Authorities (DRA)
Phases

\section{1-Exploration and 2-Programme} adoption

No official NRA or DRA or those existing have limited capacity
3-Initial implementation

NRA or DRA system set up for oversight but not fully

functional

\section{installation}

NRA or DRA with limited capacity but strategic planning in place for capacity building and appropriate budgeting
4-Full operation

Tools for quality assurance and registration of

antibiotics in place and inspection implemented but limited capacity for enforcement of policies and regulation

National policy and
plan on surveillance of
use of antimicrobials
under development
or developed and
approved but not
implemented
(surveillance in
individual facilities and
national level sales)

\section{Infection prevention control and AMR stewardship programme}

AMR stewardship
programme in healthcare
setting

No national AMR

stewardship policy or operational plan is available or approved

\begin{tabular}{ll} 
& available or approved \\
& \\
\hline National HAl and related & $\begin{array}{l}\text { No policies, limited } \\
\text { national plan and } \\
\text { guidelines to mandate } \\
\\
\text { hospitals for HAl } \\
\text { surveillance }\end{array}$
\end{tabular}

A national IPC or AMR policy or operational plan is available but weak. SOPs, guidelines, and protocols not (limited updates)

\section{Few public and private} facilities have $\mathrm{HAl}$ surveillance but data not centralised at national level available to all hospitals

\section{Monitoring sales of antimicrobials at national level not implemented. Monitoring of use is irregular and limited to few facilities that are not representative

(20) \\ ational sales data are collected on a regular basis (every $1-2$ years). Data are collected from a small and not representative sample individual healthcare facilities. No established analysis with nationa AMR laboratory based surveillance}

National IPC, AMR aligned IPC, or AMR plans implemented in limited

number of healthcare settings

\section{5-Sustainable} operation

Competent and functional NRA or DRA with capacity to ensuring or enforcing antibiotic quality standards,to take measures against substandard products and to inspect pharmacies

National sales data are collected on a regular basis (every $1-2$ years). AMU surveys are conducted in a representative sample of facilities and translated into actions. Links with national AMR surveillance data are analysed and reported

\begin{tabular}{lll}
$\begin{array}{l}\text { National IPC, AMR aligned } \\
\text { IPC, or AMR plans are } \\
\text { implemented in about all } \\
\text { healthcare settings }\end{array}$ & $\begin{array}{l}\text { IPC or AMR measures are } \\
\text { widely implemented and } \\
\text { regularly evaluated and } \\
\text { shared }\end{array}$ \\
& 3 \\
\hline $\begin{array}{l}\text { Centralised data on HAl } \\
\text { from several hospitals } \\
\text { but with limited capacity } \\
\text { for data analysis and } \\
\text { detection }\end{array}$ & $\begin{array}{l}\text { Monitoring and response } \\
\text { frameworks established } \\
\text { to identify critical HAl } \\
\text { events, especially related } \\
\text { to emergence of AMR } \\
\text { indicator bacteria against } \\
\text { critical drugs }\end{array}$ \\
\hline
\end{tabular}

\section{Research and innovation}

\section{Research and} development and innovation on AMR prevention and containment (plus research funding)

\section{Few public and private} facilities have HAI surveillance and share data at national level

\section{One Health engagement}

\begin{tabular}{|c|c|c|c|c|c|c|}
\hline $\begin{array}{l}\text { A national AMR } \\
\text { containment policy and } \\
\text { regulatory framework for } \\
\text { control of animal use and } \\
\text { their registration for use }\end{array}$ & $\begin{array}{l}\text { No national policy or } \\
\text { plan to reduce use of } \\
\text { antibiotics }\end{array}$ & $\begin{array}{l}\text { National policy } \\
\text { and plan on use } \\
\text { of antimicrobials } \\
\text { developed and } \\
\text { approved or regulatory } \\
\text { framework for control } \\
\text { of animal use and their } \\
\text { registration for use } \\
\text { is developed but not } \\
\text { implemented }\end{array}$ & $\begin{array}{l}\text { Implementation of policy } \\
\text { and plan but limited } \\
\text { capacity for monitoring use } \\
\text { and quality of drugs }\end{array}$ & $\begin{array}{l}\text { Policy and plan } \\
\text { implemented with some } \\
\text { capacity for monitoring } \\
\text { but limited capacity for } \\
\text { enforcement }\end{array}$ & $\begin{array}{l}\text { Policy and plan } \\
\text { implemented with proper } \\
\text { capacity for monitoring } \\
\text { and increased capacity for } \\
\text { enforcement }\end{array}$ & 2 \\
\hline $\begin{array}{l}\text { National surveillance of } \\
\text { AMR and use and sales of } \\
\text { antimicrobials at national } \\
\text { level in the veterinary } \\
\text { sector }\end{array}$ & $\begin{array}{l}\text { No or weak national } \\
\text { policy and guidelines }\end{array}$ & $\begin{array}{l}\text { Limited capacity for } \\
\text { surveillance of sales, } \\
\text { AMR, or AMU }\end{array}$ & $\begin{array}{l}\text { Some capacity and data } \\
\text { generated from sales, AMR } \\
\text { or AMU }\end{array}$ & $\begin{array}{l}\text { Some comparative } \\
\text { analysis of surveillance } \\
\text { data between AMR and } \\
\text { AMU }\end{array}$ & $\begin{array}{l}\text { Comprehensive approach } \\
\text { of surveillance with } \\
\text { coordinated analysis } \\
\text { between humans and } \\
\text { animals }\end{array}$ & 2 \\
\hline $\begin{array}{l}\text { Infection prevention and } \\
\text { control in the animal } \\
\text { sector }\end{array}$ & $\begin{array}{l}\text { No policy and national } \\
\text { guidelines developed } \\
\text { for biosecurity to } \\
\text { reduce infection rates } \\
\text { in food and both large } \\
\text { producers and small } \\
\text { holders }\end{array}$ & $\begin{array}{l}\text { Policies and national } \\
\text { guidelines in line with } \\
\text { international standards } \\
\text { planned including } \\
\text { vaccination policy and } \\
\text { CodexAlimentarius } \\
\text { standards }\end{array}$ & $\begin{array}{l}\text { Limited implementation, } \\
\text { particularly in large } \\
\text { producers }\end{array}$ & Full implementation & $\begin{array}{l}\text { Fully implemented in } \\
\text { multiple areas with a } \\
\text { monitoring framework } \\
\text { in place }\end{array}$ & 3 \\
\hline $\begin{array}{l}\text { AMR awareness } \\
\text { generation and } \\
\text { education in the animal } \\
\text { sector }\end{array}$ & $\begin{array}{l}\text { No policies or strategies } \\
\text { exist or are only } \\
\text { planned }\end{array}$ & $\begin{array}{l}\text { Policies or strategies } \\
\text { developed }\end{array}$ & $\begin{array}{l}\text { AMR in some pre-service } \\
\text { training or special courses } \\
\text { or both } \\
\text { OR } \\
\text { Continuous professional } \\
\text { development and regular } \\
\text { audit of learning }\end{array}$ & $\begin{array}{l}\text { AMR in some pre-service } \\
\text { training or special courses } \\
\text { or both AND Continuous } \\
\text { professional development } \\
\text { and regular audit of } \\
\text { learning }\end{array}$ & $\begin{array}{l}\text { Effect of education } \\
\text { programme on behaviour } \\
\text { changes is assessed }\end{array}$ & 1 \\
\hline
\end{tabular}

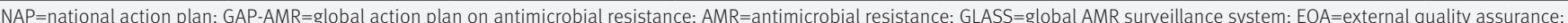
$\mathrm{API}=$ active pharmaceutical ingredient; $\mid \mathrm{PC}=$ infection, prevention, and control; $\mathrm{SOP}=$ standard operating procedures; $\mathrm{HAl}=$ health associated infection; $\mathrm{AMU}=$ antimicrobial use. 
health sectors-is non-negotiable to contain AMR in the country. ${ }^{2}$ Secondly, by highlighting common challenges it provides a sense of direction when building systems among all people and groups. Finally, we support the definition of what constitutes "sustainable operation" as provided by the tool, which includes funded programme operation bundled with a monitoring and evaluation mechanism for detecting, measuring, and interpreting changes over time.

Much has happened in the country on combating AMR since 2005. As shown, some concrete measures have been taken by the government. The ministry of health has recently developed the 2015-19 strategic plans for implementing existing regulations and guidelines and rolling out AMR related activities nationwide. These initiatives include piloting hospital and community based strategies to promote rational use of antibiotics. Local public awareness initiatives have also been taken up by non-governmental organisations and medical associations. Nevertheless, we acknowledge the urgent need to develop a comprehensive multisector national action plan, while simultaneously implementing existing evidence based AMR prevention and containment interventions. The immediate way forward is to establish an overarching governance system for AMR that will provide proper oversight of the problem and will implement sustainable strategies and interventions to policy makers. Also the AMR containment programme needs to urgently tackle three priority areas: surveillance of AMR and antimicrobial use in human health and livestock, a comprehensive strategy for raising awareness, and transforming national level policies to community outreach implementation across the country. Operational plans are being developed as part of the national action plan to tackle these priorities.

Our review has some limitations. Firstly, our findings are just a snapshot of the programme's situation, which is dynamic and can change for better or worse. These findings are as accurate and complete as the quality and diversity of the participants. This baseline analysis should be seen as the first step in a long process of a monitoring the national action plan led by WHO. We support this tool and its approach, which gives people working on the programmes the opportunity to share their perceptions of the challenges and needs and to discuss grading with external partners. This review provides a sense of direction for our national programme.

Secondly, the findings are based on broad review of systems, structures, and organisations rather than a quality analysis of documents or direct observations of performance. A good level of implementation or functionality indicates that the country is taking steps to ensure that the programme is moving towards sustainable operation, in alignment with the GAP-AMR. Moreover, a fully operational programme is not necessarily effective-a step that needs further evaluations as part of the WHO roadmap. Thirdly, some areas were not well covered by the review, such as the sanitation and hygiene programme in the community and further assessment of activities in the livestock sector. Further collaboration between the Food and Agriculture Organisation of the United Nations and WHO is warranted, as is further work on harmonising the present tool with that of WHO's Joint External Evaluation (JEE) under the International Health Regulations (2005). Lastly, we hope that other countries are encouraged by this transparent and constructive process, where WHO and national participants worked together in interactive sessions to reach a consensus.

Contributors and sources: All authors actively participated in a two day situational analysis meeting conducted in May 2016 in Jakarta, Indonesia. SV wrote the draft and all authors contributed and agreed on the contents and conclusion of the article. SV is the guarantor.

Competing interests: All authors declared no conflict of interest.

Provenance and peer review: Commissioned; externally peer reviewed.

This article is one of a series commissioned by The $B M J$ based on an idea from WHO SEARO. The BMJ retained full editorial control over external peer review, editing, and publication. Open access fees are funded by the WHO SEARO.

Harry Parathon, head of division of urogynecology reconstruction and chair $^{12}$

Kuntaman Kuntaman, clinical microbiologist and adviser $^{12}$

Tri Hesty Widiastoety, director ${ }^{3}$

Bayu T Muliawan, director ${ }^{4}$

Anis Karuniawati, clinical microbiologist and secretary ${ }^{5}$

Mariyatul Qibtiyah, pharmacist and member

Zunilda Djanun, clinical pharmacologist and member $^{6}$

Jihane F Tawilah, representative

Tjandra Aditama, senior adviser ${ }^{8}$

Visanu Thamlikitkul, WHO consultant and head of division of infectious diseases ${ }^{9}$

Sirenda Vong, regional technical lead for antimicrobial resistance ${ }^{10}$

${ }^{1}$ Faculty of Medicine, Dr Soetomo Hospital, Surabaya, Indonesia

${ }^{2}$ Antimicrobial Resistance Control Committee, Ministry of Health, Jakarta, Indonesia

${ }^{3}$ Directorate of Referral Health Services, Ministry of Health, Jakarta, Indonesia

${ }^{4}$ Directorate of Pharmaceutical Services, Ministry of Health, Jakarta, Indonesia

${ }^{5}$ Medical Faculty Universitas Indonesia, Dr. Cipto Mangunkusumo General Hospital, Jakarta, Indonesia

${ }^{6}$ Medical Faculty Universitas Indonesia, Jakarta, Indonesia
${ }^{7}$ World Health Organization, Country Office for Indonesia, Jakarta, Indonesia

${ }^{8}$ World Health Organization, Regional Office of SouthEast Asia, New Delhi

${ }^{9}$ Department of Medicine, Faculty of Medicine Siriraj Hospital, Mahidol University, Bangkok, Thailand

${ }^{10}$ World Health Organization, Regional Office of South East Asia, New Delhi, India

Correspondence to: SVong

vongs@who.int

Global Action Plan on Antimicrobial Resistance. World Health Organization. 2015. www.who.int/ antimicrobial-resistance/publications/global-actionplan/en/

2 World Health Organization. 68th World Health Assembly Resolutions on antimicrobial resistance. 2015. who.int/mediacentre/news/releases/2015/ wha-25-may-2015/en/

Kakkar M, Walia K, Vong S, et al. Antibiotic resistance and its containment in India. BMJ 2017;358:j2687.

World bank data. data.worldbank.org/country/ indonesia

Antimicrobial resistance: Global report on surveillance. World Health Organization. 2014 www.who.int/drugresistance/documents/ surveillancereport/en/

6 Safari D, Kurniati N, Waslia L, et al. Serotype distribution and antibiotic susceptibility of Streptococcus pneumoniae strains carried by children infected with human immunodeficiency virus. PLoS One 2014;9:e110526. doi:10.1371/ journal.pone.0110526

7 Lestari ES, Severin JA. Antimicrobial resistance in Indonesia: Prevalence, determinants and genetic basis. 2009. PhD thesis. repub.eur.nl/pub/17713/

8 Soewignjo S, Gessner BD, Sutanto A, et al. Streptococcus pneumoniae nasopharyngeal carriage prevalence, serotype distribution, and resistance patterns among children on Lombok Island, Indonesia. Clin Infect Dis 2001;32:1039-43. doi:10.1086/319605

9 European Centre for Disease Control and Prevention. European Antimicrobial Resistance Surveillance Network (EARS-Net). www.rivm.nl/earss/database

10 Farida H, Severin JA, Gasem MH, et al. Nasopharyngeal carriage of Streptococcus pneumonia in pneumonia-prone age groups in Semarang, Java Island, Indonesia. PLoS One 2014;9:e87431.

11 Severin JA, Mertaniasih NM, Kuntaman K, et al. Study Group 'Antimicrobial Resistance in Indonesia: Prevalence and Prevention' (AMRIN). Molecular characterization of extended-spectrum beta-lactamases in clinical Escherichia coli and Klebsiella pneumoniae isolates from Surabaya, Indonesia. J Antimicrob Chemother 2010;65:465-9. doi:10.1093/jac/dkp471

12 Bonnet R. Growing group of extended-spectrum beta-lactamases: the CTX-M enzymes. Antimicrob Agents Chemother 2004;48:1-14. doi:10.1128/ AAC.48.1.1-14.2004

13 Cantón R, Coque TM. The CTX-M beta-lactamase pandemic. Curr Opin Microbiol 2006;9:466-75. doi:10.1016/j.mib.2006.08.011

14 Lestari ES, Severin JA, Filius PM, et al. Antimicrobial Resistance in Indonesia: Prevalence and prevention (AMRIN). Antimicrobial resistance among commensal isolates of Escherichia coli and Staphylococcus aureus in the Indonesian population inside and outside hospitals. Eur J Clin Microbiol Infect Dis 2008;27:45-51. doi:10.1007/s10096-007 0396-Z

15 Xu Y, Gu B, Huang M, et al. Epidemiology of carbapenem resistant Enterobacteriaceae (CRE) during 2000-2012 in Asia. / Thorac Dis 2015:7:376-85.

16 Al-Dhaheri AS, Al-Niyadi MS, Al-Dhaheri AD, Bastaki SM. Resistance patterns of bacterial isolates to antimicrobials from 3 hospitals in the United Arab Emirates. Saudi Med / 2009;30:618-23.

17 Khorasani G, Salehifar E, Eslami G. Profile of microorganisms and antimicrobial resistance at a tertiary care referral burn centre in Iran: emergence of Citrobacter freundii as a common microorganism. 
Burns 2008;34:947-52. doi:10.1016/j. burns.2007.12.008

18 Karuniawati A, Saharman YR, Lestari DC. Detection of carbapenemase encoding genes in Enterobacteriace, Pseudomonas aeruginosa, and Acinetobacter baumanii isolated from patients at Intensive Care Unit Cipto Mangunkusumo Hospital in 2011. Acta Med Indones 2013;45:101-6.

19 Severin JA, Lestari ES, Kuntaman K, et al. Antimicrobial Resistance in Indonesia, Prevalence and Prevention Study Group. Unusually high prevalence of pantonvalentine leukocidin genes among methicillinsensitive Staphylococcus aureus strains carried in the Indonesian population. J Clin Microbiol 2008;46:198995. doi:10.1128/JCM.01173-07

20 Zhao $\mathrm{C}$, Sun $\mathrm{H}$, Wang $\mathrm{H}$, et al. Antimicrobial resistance trends among 5608 clinical Gram-positive isolates in China: results from the Gram-Positive Cocci Resistance Surveillance program (2005-2010). Diagn Microbiol Infect Dis 2012;73:174-81. doi:10.1016/j.diagmicrobio.2012.03.003

21 Xiao YH, Giske CG, Wei ZQ, Shen P, Heddini A, Li LJ. Epidemiology and characteristics of antimicrobial resistance in China. Drug Resist Updat 2011;14:236-50. doi:10.1016/j. drup.2011.07.001

22 Vandenesch F, Naimi T, Enright MC, et al. Communityacquired methicillin-resistant Staphylococcus aureus carrying Panton-Valentine leukocidin genes: worldwide emergence. Emerg Infect Dis 2003;9 978-84. doi:10.3201/eid0908.030089

23 Van Boeckel TP, Brower C, Gilbert M, et al. Global trends in antimicrobial use in food animals. Proc Natl
Acad Sci U S A 2015;112:5649-54. doi:10.1073/ pnas.1503141112

24 Hadi U, Duerink DO, Lestari ES, et al. Antimicrobial Resistance in Indonesia 'Prevalence and Prevention' study group. Survey of antibiotic use of individuals visiting public healthcare facilities in Indonesia. Int I Infect Dis 2008;12:622-9. doi:10.1016/j. ijid.2008.01.002

25 Marjadi B, McLaws ML. Hand hygiene in rural Indonesian healthcare workers: barriers beyond sinks, hand rubs and in-service training. J Hosp Infect 2010;76:256-60. doi:10.1016/j. jhin.2010.06.021.

Cite this as: BMJ 2017;358:j3808 http://dx.doi.org/10.1136/bmj.j3808

This an open access article distributed under the terms of the Creative Commons Attribution-non-commercial IGO License (https:// creativecommons.org/licenses/by-nc/3.0/igo/), which permits use, distribution, and reproduction for non-commercial purposes in any medium, provided the original work is properly cited. In any reproduction of this article there should not be any suggestion that WHO or this article endorse any specific organisation or products. The use of the WHO logo is not permitted. This notice should be preserved along with the article's original URL 